\title{
Induksi Umbi Mikro Kentang Secara In Vitro Pada Suhu Tinggi Dengan Beberapa Tuber Promoter
}

\author{
USMAN KRIS JOKO SUHARJO ${ }^{1}$, BAMBANG GONGGO MURCITRO ${ }^{2}$, \\ TUNJUNG PAMEKAS ${ }^{3}$, HARYUNI $^{4}$ \\ ${ }^{1}$ Jurusan Budidaya Tanaman, Fakultas Pertanian, Universitas Bengkulu \\ Jl. Raya W.R. Supratman, Kandanglimun, Bengkulu 38371 \\ email: usman_maine@yahoo.com; usmankris@unib.ac.id \\ ${ }^{2}$ Program Studi Ilmu Tanah, Fakultas Pertanian, Universitas Bengkulu \\ J1. Raya W.R. Supratman, Kandanglimun, Bengkulu 38371 \\ email: bambanggonggo@unib.ac.id \\ ${ }^{3}$ Jurusan Perlindungan Tanaman, Fakultas Pertanian, Universitas Bengkulu \\ Jl. Raya W.R. Supratman, Kandanglimun, Bengkulu 38371 \\ email: tunjungpamekas@unib.ac.id \\ ${ }^{4}$ Program Studi Agroekoteknologi, Jurusan Budidaya Tanaman, Fakultas Pertanian, \\ Universitas Bengkulu \\ Jl. Raya W.R. Supratman, Kandanglimun, Bengkulu 38371 \\ email: haryuni66@gmail.com
}

\begin{abstract}
Potato microtubers are the miniature of conventional seed tubers grown in the field. Producing potato microtuber in vitro at high temperature by applying many kinds of tuber promoting substances is similar to producing potato in the field at low elevation by applying the same tuber promoting substances. The objective of this research was to evaluate the performance of seven tuber promoters in inducing potato microtubers at high temperatures. Micro cuttings ( 6 weeks old) were grown at the liquid media of MS for stolon induction. Six weeks afterward, the media were moved to microtuber inducing media supplemented with tuber promoters $((\mathrm{FD}, \mathrm{FD}+10 \mathrm{COU}, \mathrm{FD}+20 \mathrm{COU}$, $\mathrm{FD}+30 \mathrm{COU}, \mathrm{FD}+40 \mathrm{COU}, \mathrm{FD}+50 \mathrm{COU}$, and IPB). The media were incubated in the dark at $20 \pm$ $2^{\circ} \mathrm{C}$ and $29 \pm 2^{\circ} \mathrm{C}$. The results showed that, in general, high temperature inhibited crop growth and tuber formation. Individually, tuber promoter formula significantly affected microtuber emergence, in which IPB showed the slowest treatment in producing microtubers, the smallest number of tuber produced, and the smallest size of tubers. The interaction between temperature and tuber promoters were significantly affected the tuber formation, in which the fastest tuber formation (7,0 days ) was found in FD $+40 \mathrm{COU}$ and the highest percentage of plant producing tubers was found in FD +30 COU. Moreover, the highest number of microtuber and the heaviest weight of microtuber were found in FD (no Coumarin). It was safely concluded that all tuber promoters were best performed at low temperature. Should anyone wish to make those tuber promoters work better at high temperature, it is recommended to increase the concentration of Coumarin added to the formula of tuber promoting substances.
\end{abstract}

Keywords: high temperature, in vitro, potato microtubers, tuber promoter

\section{INTISARI}

Umbi mikro kentang merupakan miniatur umbi kentang yang digunakan sebagai benih untuk penanaman di lahan. Produksi umbi mikro kentang pada suhu tinggi dengan zat pemacu pembentukan umbi (tuber promoter) dijadikan sebagai simulasi produksi kentang di dataran rendah dengan menggunakan formula tuber promoter. Tujuan penelitian ini adalah mengkaji pembentukan umbi mikro kentang pada suhu tinggi dengan berbagai formula tuber promoter. Stek mikro kentang berusia 6 minggu tanpa akar dan pucuk ditanam pada media cair untuk menginduksi pembentukan stolon. Pada usia 6 minggu stek mikro dipindahkan ke media induksi umbi mikro yang telah diberi 
7 formula tuber promoter (FD, FD+10 COU, FD+20 COU, FD+30 COU, FD+40 COU, FD+50 $\mathrm{COU}$, dan IPB). Media dan stek mikro diinkubasi pada kondisi gelap total dengan suhu $20 \pm 2{ }^{\circ} \mathrm{C}$ dan $29 \pm 2{ }^{\circ} \mathrm{C}$. Hasil penelitian menunjukkan bahwa, secara umum, suhu tinggi menghambat pertumbuhan tanaman dan pembentukan umbi. Secara tunggal, formula tuber promoter hanya berpengaruh nyata pada inisiasi umbi, formula IPB menunjukkan waktu keluar umbi (WKU) paling lama, jumlah umbi (JU) paling sedikit, dan diameter umbi (DU) paling kecil. Terdapat interaksi yang nyata antara suhu dan formula tuber promoter dalam mempengaruhi variabel-variabel yang diukur. Semua tuber promoter menunjukkan hasil terbaiknya pada suhu rendah $\left(20 \pm 2{ }^{\circ} \mathrm{C}\right)$, dengan WKU tercepat (7,0 hari) diperoleh pada FD + $40 \mathrm{COU}$, persen tanaman produktif (PTP) paling tinggi diperoleh pada FD + $30 \mathrm{COU}$, JU terbanyak dan DU terbesar dihasilkan oleh formula FD. Dengan demikian dapat disimpulkan bahwa semua tuber promoter bekerja dengan sangat baik pada suhu rendah. Apabila tuber promoter diharapkan dapat bekerja dengan baik pada suhu tinggi, maka disarankan untuk meningkatkan konsentrasi Coumarinnya.

Kata kunci: in vitro, suhu tinggi, tuber promoter, umbi mikro kentang

\section{PENDAHULUAN}

Umbi mikro kentang adalah miniatur benih kentang yang dihasilkan melalui teknik kultur jaringan tanaman (Saha et al., 2013). Umbi mikro ini bebas hama, bebas patogen, dan sangat potensial untuk menjadi bibit unggul (Badoni and Chauhan, 2010). Pada program produksi benih unggul, umbi mikro ditanam pada media steril di screenhouse untuk menghasilkan umbi mini, yang termasuk kategori nuclear seeds. Dalam proses produksi benih unggul, nuclear seeds juga dapat diproduksi dengan menanam stek mikro di screenhouse (Suharjo et al., 2010). Namun demikian, penggunaan stek mikro masih harus melewati tahap aklimatisasi, yang memiliki resiko kegagalan yang tinggi. Sementara itu, penggunaan umbi mikro dapat mengatasi masalah yang sering dihadapi pada saat aklimatisasi stek mikro. Selain itu, umbi mikro dapat disimpan, dikirim, dan ditanam dengan mudah (Badoni and Chauhan, 2010).

Ukuran umbi mikro menjadi indikasi keberhasilan penampilannya di lapangan. Semakin besar ukuran umbi semakin baik tampilannya di lapangan (Kawakami and Iwama, 2012). Oleh karena itu, memproduksi umbi mikro dengan ukuran besar menjadi sangat penting. Dengan menggunakan 10, 20, 25, dan $30 \mathrm{mg} . \mathrm{L}^{-1}$ Coumarin, Kianmher et al. (2012) mendapatkan bahwa jumlah dan ukuran umbi terus meningkat dengan meningkatnya konsentrasi Coumarin pada media tanam. Peningkatan jumlah umbi juga dapat dilakukan dengan menambahkan BAP ke media pembawa. Dengan menambahkan 2 mg.L L $^{-1}$ BAP, Piao et al. (2002) memperoleh 25 umbi per botol, sementara itu tanpa BAP hanya diperoleh 15 umbi per botol. Kanwal et al. (2006) menggunakan Kinetin dan BAP untuk menginduksi pembentukan umbi mikro kentang varietas Kuroda di media cair mampu memberikan hasil lebih baik dari pada media padat. Hasil terbaik diperoleh pada konsentrasi 0,75 mg. $\mathrm{L}^{-1}$ BAP.

Selain zat pengatur tumbuh (ZPT) yang digunakan, keberhasilan teknik kultur jaringan tanaman kentang dalam menghasilkan umbi mikro juga sangat dipengaruhi oleh formula media dan suhu inkubasi ruang kulturnya (Otroshy et al., 2009). Suhu inkubasi yang tinggi menghambat pembentukan umbi kentang (Suharjo et al., 2008), karena tanaman kentang menghendaki suhu rendah untuk dapat tumbuh dengan baik dan berproduksi secara maksimal (Stark and Love, 2003). Hasil penelitian Otroshy et al. (2009) menunjukkan bahwa terjadi penurunan persentase tanaman berumbi dari $88 \%$ ke $64 \%$, jumlah umbi per tanaman dari $0,88 \mathrm{ke}$ 0,66 buah, dan ukuran umbi dari $2.2 \mathrm{~mm} \mathrm{ke}$ 1,6 $\mathrm{mm}$ ketika suhu ruang inkubasi dinaikkan dari $17^{\circ} \mathrm{C}$ ke $25^{\circ} \mathrm{C}$. Namun demikian, efek negatif suhu tinggi di ruang kultur dapat diatasi dengan meningkatkan konsentrasi ZPT, khususnya jenis retardan yang digunakan (Suharjo et al., 2008). Suharjo et 
al. (2008) melaporkan bahwa umbi mikro kentang dapat diproduksi pada suhu tinggi $\left(30^{\circ} \mathrm{C}\right.$ siang hari; $25^{\circ} \mathrm{C}$ malam hari) dengan pemberian Paclobutrazol (4000 ppm), CCC (1200 ppm), Coumarin (200 ppm), dan Ancymidol (4ppm).

Memadukan berbagai unsur yang memacu pembentukan umbi mikro mulai digemari oleh para peneliti. Harapannya, paduan beberapa bahan kimia yang diramu dalam suatu formula itu dapat memacu pembentukan umbi mikro pada suhu tinggi. Dalam hal ini, penulis telah meramu auksin, sitokinin, retardan, asam organik, chitosan, arang aktif, dan air kelapa dalam beberapa bentuk formula yang diberi nama Tuber Promoter. Chitosan mempunyai peranan yang sangat penting dalam meningkatkan ketahanan eksplan tanaman kentang terhadap stres lingkungan pada saat aklimatisasi (Zakaria et al., 2009). Peran auksin, sitokinin, asam organik, chitosan, air kelapa, dan retardan secara individu sudah banyak dilaporkan (Suharjo et al., 2008; Zakaria et al., 2009; Fufa and Diro, 2014). Lebih lanjut dilaporkan bahwa kombinasi antara auksin, sitokinin, dan retardan memberikan hasil terbaik dalam menginduksi umbi mikro kentang varietas Kufru Jyoti (Dhaka and Nailwal, 2015). Informasi ini mendorong peneliti untuk memadukan lebih dari satu unsur dalam memacu pembentukan umbi secara in vitro. Pada penelitian ini dipadukan auksin, sitokinin, chitosan, asam organik, air kelapa dan retardan dalam beberapa formula untuk memacu pembentukan umbi mikro.

Menguji pengaruh Tuber Promoter dalam menginduksi umbi mikro kentang secara in vitro pada suhu tinggi dapat digunakan sebagai model dalam sistem produksi kentang di dataran rendah. Tujuan utama penelitian ini adalah mengkaji pembentukan umbi mikro kentang pada suhu tinggi dengan berbagai formula tuber promoter.

\section{METODE}

Penelitian dilakukan di Laboratorium Kultur Jaringan, Program Studi Agroekoteknologi, Jurusan Budidaya Pertanian, Fakultas Pertanian, Universitas
Bengkulu. Penelitian ini menggunakan rancangan percobaan acak lengkap (Randomized Complete Design/RCD) yang disusun secara faktorial dengan 2 faktor dan 10 ulangan. Faktor pertama yang diuji adalah suhu inkubasi yang terdiri dari suhu rendah $\left(20 \pm 2^{\circ} \mathrm{C}\right)$ dan suhu tinggi $\left(29 \pm 2^{\circ} \mathrm{C}\right)$. Faktor kedua yang diuji adalah formula tuber promoter yang terdiri dari formula dasar dengan penambahan Coumarin $(10,20,30$, 40, $50 \mathrm{mg} . \mathrm{L}^{-1}$ ) dan formula IPB sebagai kontrol. Formula dasar yang digunakan pada penelitian ini adalah media MS yang diberi suplemen auksin, sitokinin, chitosan, dan asam organik. Jenis dan konsentrasi bahan penyusun formula dasar tidak dapat disampaikan pada laporan ini untuk tujuan paten. Formula IPB adalah 2,4-D (10 ppm) dan Daminozide (100 ppm) dan 10\% air kelapa yang ditambahkan ke media MS lengkap.

Bahan tanaman yang digunakan adalah stek mikro kentang lokal berkulit merah berusia 6 minggu yang telah disub-kultur dua kali. Bahan lain yang digunakan adalah garam makro dan mikro penyusun media MS, vitamin, dan asam amino, gula pasir, dan zat pengatur tumbuh (ZPT) penyusun formula tuber promoter.

Produksi umbi mikro dilakukan dengan mengadopsi metode Zhang and Donelly (1997) yang dimodifikasi oleh Suharjo (2007), yang terdiri dari induksi stolon dan induksi umbi. Pada induksi stolon, 5 batang stek mikro umur 6 minggu tanpa akar dan pucuk ditanam pada $20 \mathrm{ml}$ media cair steril yang berisi garam mineral MS dengan suplemen myoniositol $\left(100 \mathrm{mg} . \mathrm{L}^{-1}\right)$, thiamin $\left(0,1 \mathrm{mg} \cdot \mathrm{L}^{-1}\right)$, niotinic acid $\left(0,5 \mathrm{mg} \cdot \mathrm{L}^{-1}\right)$, pyridoxin $\left(0,5 \mathrm{mg} . \mathrm{L}^{-1}\right)$, dan glycine $(2,0$ mg. $\left.L^{-1}\right)$, gula $\left(30\right.$ g. $\left.\mathrm{L}^{-1}\right), \mathrm{GA}_{3}\left(0,4 \mathrm{mg} \cdot \mathrm{L}^{-1}\right)$, dan BAP $\left(0,5 \mathrm{mg} \cdot \mathrm{L}^{-1}\right)$, dengan $\mathrm{pH}$ media 5,8 . Sterilisasi media dilakukan dengan autoklaf pada tekanan 15 psi dan suhu $121^{\circ} \mathrm{C}$ selama 20 menit. Media dan eksplan tanaman kentang diinkubasi pada suhu $20 \pm 2^{\circ} \mathrm{C}$ dengan lama penyinaran 12 jam dengan lampu halogen.

Enam minggu kemudian, eksplan tanaman kentang dipindahkan ke media 
induksi umbi mikro. Cara menyiapkan media induksi umbi mikro sama persis dengan cara menyiapkan media induksi stolon. Isi media induksi umbi mikro juga sama persis dengan isi media induksi stolon dengan sedikit modifikasi, yaitu tanpa $\mathrm{GA}_{3}$ dan sitokinin, kandungan gulanya ditingkatkan menjadi 80 mg. $\mathrm{L}^{-1}$ dan mendapat tambahan tuberin sesuai dengan formula yang diuji. Eksplan diinkubasi pada suhu berbeda dengan kondisi gelap total. Efek gelap total diciptakan dengan menempatkan botol kultur di dalam kardus yang dibungkus rapat dengan kain hitam.

Variabel yang diamati meliputi kecepatan menghasilkan umbi mikro (hari ke-), persentase tanaman produktif, jumlah umbi per botol, bobot umbi per botol, dan diameter umbi. Data dianalisis dengan analysis of variance (ANOVA) dan uji nilai tengah dengan Duncan Multiple's Range Test (DMRT) pada taraf 5\%.

\section{HASIL}

Hasil analisis keragaman menunjukkan bahwa suhu berpengaruh nyata terhadap semua variabel yang diukur, kecuali jumlah cabang utama dan jumlah ruas tanaman, coumarin tidak berpengaruh nyata terhadap semua variabel yang diukur kecuali jumlah umbi per botol dan obor umbi per botol, dan interaksi antara suhu dan coumarin hanya berpengaruh nyata pada variabel jumlah umbi dan bobot umbi per botol.

Pengaruh Suhu. Perlakuan suhu berpengaruh nyata terhadap semua variabel pertumbuhan tanaman yang diukur, kecuali jumlah cabang dan jumlah ruas tanaman (Tabel 1). Secara umum, suhu rendah $(20 \pm$ $\left.2^{\circ} \mathrm{C}\right)$ memberikan pertumbuhan yang lebih baik bagi eksplan tanaman kentang, yang ditunjukkan dengan jumlah cabang lebih banyak dan bobot brangkasan kering lebih tinggi.

Tabel 1. Pengaruh suhu inkubasi terhadap pertumbuhan eksplan dan produksi umbi mikro.

\begin{tabular}{lcc}
\multicolumn{1}{c}{ Variabel } & \multicolumn{2}{c}{ Suhu inkubasi } \\
\cline { 2 - 3 } Jumlah cabang (buah) & $18 \pm 2^{\circ} \mathrm{C}$ & $29 \pm 2^{\circ} \mathrm{C}$ \\
\hline Jumlah ruas (buah) & $2,37 \mathrm{a}$ & $1,91 \mathrm{a}$ \\
\hline Tinggi tanaman (cm) & $7,21 \mathrm{a}$ & $5,29 \mathrm{a}$ \\
\hline Bobot basah eksplan (g) & $3,81 \mathrm{a}$ & $5,94 \mathrm{~b}$ \\
\hline Saat keluar umbi (hari) & $5,67 \mathrm{a}$ & $2,21 \mathrm{~b}$ \\
\hline Tanaman berumbi (\%) & $17,21 \mathrm{a}$ & $30,21 \mathrm{~b}$ \\
\hline Umbi per botol (buah) & $88,51 \mathrm{a}$ & $7,94 \mathrm{~b}$ \\
\hline Bobot umbi (g) & $7,63 \mathrm{a}$ & $0,21 \mathrm{~b}$ \\
\hline Diameter umbi (mm) & $1,63 \mathrm{a}$ & $0,02 \mathrm{~b}$ \\
\hline
\end{tabular}

Keterangan: angka-angka yang diikuti oleh huruf berbeda pada baris yang sama berbeda nyata pada taraf $5 \%$

Pada suhu rendah $\left(18 \pm 2^{\circ} \mathrm{C}\right)$, eksplan tanaman kentang hanya memerlukan 17,1 hari untuk menghasilkan umbi, sedangkan pada suhu tinggi $\left(29 \pm 2^{\circ} \mathrm{C}\right)$ diperlukan 30,1 hari. Selain itu, pada suhu rendah didapatkan $88,5 \%$ tanaman menghasilkan umbi, dengan jumlah umbi per botol mencapai 7,63 buah, berbobot total $1,63 \mathrm{~g}$, dan rata-rata diameter umbinya mencapai $6,78 \mathrm{~mm}$. Hasil ini jauh lebih baik dibandingkan pada suhu tinggi (Tabel 1).

Pengaruh Tuber Promoter. Tuber promoter tidak berpengaruh nyata terhadap pertumbuhan eksplan tanaman kentang di dalam botol kultur, kecuali bobot basah eksplan (BBE). Pemberian tambahan coumarin pada formula dasar tidak memberikan pengaruh yang nyata pada tinggi tanaman (TT), jumlah cabang (JC), dan jumlah ruas tanaman (JR).

Nilai BKB terendah $(2,32 \mathrm{~g})$ ditunjukkan oleh formula IPB dan BKB tertinggi $(6,21 \mathrm{~g})$ diperoleh pada perlakuan formula dasar plus 40 ppm coumarin (FD + $40 \mathrm{COU})$. Dalam hal ini nilai BBE perlakuan FD dan FD +20 COU tidak berbeda nyata dengan nilai BBE pada formula IPB (Tabel 2). 
Tabel 2. Pengaruh formula tuber promoter terhadap tinggi tanaman (TT), jumlah cabang (JC), jumlah ruas (JR), dan bobot basah eksplan (BBE).

\begin{tabular}{|c|c|c|c|c|}
\hline Perlakuan & TT $(\mathrm{cm})$ & JC (buah) & JR (buah) & BBE (gr) \\
\hline FD & $4,21 \mathrm{a}$ & $1,65 \mathrm{a}$ & $7,11 \mathrm{a}$ & $3,57 \mathrm{a}$ \\
\hline FD $+10 \mathrm{COU}$ & $3,12 \mathrm{a}$ & $1,71 \mathrm{a}$ & $6,79 \mathrm{a}$ & $4,65 \mathrm{ab}$ \\
\hline $\mathrm{FD}+20 \mathrm{COU}$ & $3,54 \mathrm{a}$ & $1,26 \mathrm{a}$ & $6,91 \mathrm{a}$ & $3,99 \mathrm{a}$ \\
\hline FD $+30 \mathrm{COU}$ & $4,12 \mathrm{a}$ & $1,57 \mathrm{a}$ & $7,21 \mathrm{a}$ & $5,32 \mathrm{bc}$ \\
\hline $\mathrm{FD}+40 \mathrm{COU}$ & $3,11 \mathrm{a}$ & $1,32 \mathrm{a}$ & $7,01 \mathrm{a}$ & $6,21 \mathrm{c}$ \\
\hline FD + $50 \mathrm{COU}$ & $2,54 \mathrm{a}$ & $1,91 \mathrm{a}$ & $6,97 \mathrm{a}$ & $5,87 \mathrm{bc}$ \\
\hline IPB & $3,61 \mathrm{a}$ & $1,57 \mathrm{a}$ & $5,99 \mathrm{a}$ & $2,32 \mathrm{a}$ \\
\hline
\end{tabular}

Keterangan: angka-angka yang diikuti oleh huruf berbeda pada kolom yang sama berbeda nyata pada taraf 5\%; FD = formula dasar; FD $+10 \mathrm{CU}=$ Formula dasar ditambah 10 ppm Coumarin.

Tuber promoter berpengaruh nyata terhadap waktu keluarnya umbi (WKU), persen tanaman produktif (PTP), jumlah umbi per botol (JU), dan bobot umbi (BU), sebagaimana ditunjukkan pada Tabel 3.

Tabel 3. Pengaruh formula tuber promoter terhadap waktu keluarnya umbi (WKU), persen tanaman produktif (PTP), jumlah umbi (JU), dan bobot umbi (BU).

\begin{tabular}{lcccc}
\hline Perlakuan & WKU (hari) & PTP (\%) & JU (buah) & BU (gr) \\
\hline FD & $14,0 \mathrm{a}$ & $48,3 \mathrm{a}$ & $4,9 \mathrm{~b}$ & $1,13 \mathrm{~b}$ \\
\hline FD +10 COU & $14,1 \mathrm{a}$ & $56,2 \mathrm{~b}$ & $4,3 \mathrm{~b}$ & $1,08 \mathrm{~b}$ \\
\hline FD +20 COU & $24,5 \mathrm{ab}$ & $46,3 \mathrm{a}$ & $4,3 \mathrm{~b}$ & $0,87 \mathrm{ab}$ \\
\hline FD +30 COU & $14,1 \mathrm{a}$ & $47,4 \mathrm{a}$ & $3,8 \mathrm{~b}$ & $0,75 \mathrm{ab}$ \\
\hline FD +40 COU & $24,5 \mathrm{ab}$ & $48,5 \mathrm{a}$ & $4,2 \mathrm{~b}$ & $0,57 \mathrm{a}$ \\
\hline FD +50 COU & $31,5 \mathrm{bc}$ & $44,3 \mathrm{a}$ & $3,9 \mathrm{~b}$ & $0,97 \mathrm{ab}$ \\
\hline IPB & $49,1 \mathrm{c}$ & $47,8 \mathrm{a}$ & $1,2 \mathrm{a}$ & $0,43 \mathrm{a}$ \\
\hline
\end{tabular}

Keterangan: angka-angka yang diikuti oleh huruf berbeda pada kolom yang sama berbeda nyata pada taraf $5 \%$. FD = formula dasar; FD + $10 \mathrm{CU}=$ Formula dasar ditambah 10 ppm Coumarin.

Tabel 4. Pengaruh interaksi antara suhu dan tuber promoter terhadap waktu keluarnya umbi (WKU), persen tanaman produktif (PTP), jumlah umbi (JU), dan bobot umbi (BU).

$\begin{array}{lllll}\text { Perlakuan } & \text { WKU (hari) } & \text { PTP (\%) } & \text { JU (buah) } & \text { BU (gr) }\end{array}$

Suhu Inkubasi $18 \pm 2^{\circ} \mathrm{C}$

\begin{tabular}{|c|c|c|c|c|}
\hline FD & $14,0 \mathrm{ab}$ & $87,9 \mathrm{c}$ & $9,7 \mathrm{~d}$ & $2,238 \mathrm{c}$ \\
\hline FD $+10 \mathrm{COU}$ & $14,1 \mathrm{ab}$ & $95,1 \mathrm{de}$ & $8,2 \mathrm{~cd}$ & $2,087 \mathrm{bc}$ \\
\hline FD + $20 \mathrm{COU}$ & $14,3 \mathrm{ab}$ & $97,7 \mathrm{e}$ & $8,5 \mathrm{~cd}$ & $1,751 \mathrm{bc}$ \\
\hline FD $+30 \mathrm{COU}$ & $14,0 \mathrm{ab}$ & $79,4 \mathrm{c}$ & $7,6 \mathrm{bc}$ & $1,484 \mathrm{~b}$ \\
\hline $\mathrm{FD}+40 \mathrm{COU}$ & $7,0 \mathrm{a}$ & $90,7 \mathrm{c}$ & $8,3 \mathrm{~cd}$ & $1,113 \mathrm{~b}$ \\
\hline FD + $50 \mathrm{COU}$ & $21,2 b c$ & 82,9 a & $7,6 \mathrm{bc}$ & $1,873 \mathrm{bc}$ \\
\hline IPB & 35,2 cde & $91,4 \mathrm{de}$ & $2,8 \mathrm{ab}$ & $0,872 \mathrm{ab}$ \\
\hline \multicolumn{5}{|c|}{ Suhu Inkubasi $29 \pm 2^{\circ} \mathrm{C}$} \\
\hline FD & $14,2 \mathrm{ab}$ & $8,52 \mathrm{a}$ & $0,1 \mathrm{a}$ & $0,027 \mathrm{a}$ \\
\hline FD + $10 \mathrm{COU}$ & $14,1 \mathrm{ab}$ & $14,25 \mathrm{a}$ & $0,3 \mathrm{a}$ & $0,081 \mathrm{a}$ \\
\hline FD $+20 \mathrm{COU}$ & 35,2 cde & $2,86 \mathrm{a}$ & $0,1 \mathrm{a}$ & $0,004 \mathrm{a}$ \\
\hline FD $+30 \mathrm{COU}$ & $14,1 \mathrm{ab}$ & $15,71 \mathrm{a}$ & $0,1 \mathrm{a}$ & $0,023 \mathrm{a}$ \\
\hline $\mathrm{FD}+40 \mathrm{COU}$ & $42,1 \mathrm{de}$ & $5,71 \mathrm{a}$ & $0,2 \mathrm{a}$ & $0,021 \mathrm{a}$ \\
\hline FD + $50 \mathrm{COU}$ & $42,1 \mathrm{de}$ & $5,71 \mathrm{a}$ & $0,2 \mathrm{a}$ & $0,061 \mathrm{a}$ \\
\hline IPB & $49,4 \mathrm{e}$ & $2,86 \mathrm{a}$ & $0,1 \mathrm{a}$ & $0,007 \mathrm{a}$ \\
\hline
\end{tabular}

Keterangan: angka-angka yang diikuti oleh huruf berbeda pada baris yang sama berbeda nyata pada taraf 5\%; FD = formula dasar; FD + $10 \mathrm{CU}=$ Formula dasar ditambah 10 ppm Coumarin. 
WKU paling cepat adalah 14,0 hari yang dihasilkan oleh perlakuan tuber promoter tanpa penambahan coumarin (FD), sedangkan WKU paling lama dihasilkan oleh perlakuan formula IPB $(49,1$ hari). WKU pada perlakuan lainnya berada pada kisaran 14.1 sampai 31,5 hari (Tabel 3).

Persen tanaman produktif (PTP) tertinggi $(56,2 \%)$ dihasilkan oleh perlakuan tuber promoter dengan penambahan coumarin 10 ppm (FD + 10 COU). Pada perlakuan lain, PTP-nya berkisar pada angka 44,3 - 48,5\%.

Jumlah umbi (JU) yang dihasilkan oleh perlakuan tuber promoter jauh lebih banyak dibandingkan perlakuan IPB. Formula IPB hanya menghasilkan 1,2 umbi, sedangkan perlakuan lainnya menghasilkan tiga sampai empat kali lipat yang dihasilkan oleh formula IPB (Tabel 4).

Bobot umbi (BU) paling tinggi ditunjukkan oleh perlakuan FD dan FD + 10 COU, masing-masing adalah $1,13 \mathrm{~g}$ dan 1,02 g, sedangkan BU paling kecil diperoleh pada perlakuan formula IPB, yaitu $0,43 \mathrm{~g}$.

Pengaruh Suhu dan Tuber Promoter. Interaksi suhu dan tuber promoter tidak berpengaruh nyata terhadap variabel pertumbuhan; akan tetapi, berpengaruh nyata terhadap variabel inisiasi umbi. Data pertumbuhan tidak disajikan pada laporan ini. Data tentang inisasi umbi disajikan pada Tabel 4 dan Tabel 5.

Secara umum, terjadi penundaan pembentukan umbi kentang pada suhu tinggi, meskipun tanaman sudah mendapatkan perlakuan tuber promoter, baik dengan tambahan coumarin atau tidak (Tabel 4). Pada suhu rendah $\left(20 \pm 2{ }^{\circ} \mathrm{C}\right)$, waktu munculnya umbi (WKU) tercepat $(7,1$ hari) ditunjukkan oleh perlakukan FD + 40 COU; sedangkan WKU terlama dihasilkan oleh formula IPB (35,2 hari). Polanya berubah pada suhu tinggi, di mana MKU paling cepat adalah 14,1 hari, yang ditunjukkan oleh perlakuan FD, FD + $10 \mathrm{COU}, \mathrm{FD}+30 \mathrm{COU}$. Pada suhu rendah, MKU perlakuan FD +40 COU adalah 42,3 hari, yang tidak berbeda nyata dengan formula IPB (49,1 hari).

Persen tanaman produktif (PTP) dipengaruhi oleh suhu dan tuber promoter yang digunakan. Pada suhu tinggi, semua tuber promoter tidak efektif dalam pembentukan umbi mikro sehingga hanya $2,86-15,71 \%$ tanaman yang mampu berumbi. Sebaliknya, pada suhu rendah tuber promoter sangat efektif dalam membentuk umbi. Pada kondisi ini, 79,4 - 97,7\% tanaman berumbi (Tabel 4).

Jumlah umbi paling banyak (9,7 buah) dihasilkan oleh tuber promoter FD pada suhu rendah $\left(20 \pm 2{ }^{\circ} \mathrm{C}\right)$. Sebaliknya, pada suhu tinggi $\left(29 \pm 2{ }^{\circ} \mathrm{C}\right)$ tuber promoter hanya mampu menghasilkan paling banyak 0,3 buah umbi mikro (Tabel 4). Rendahnya jumlah umbi terbentuk pada suhu tinggi berakibat pada rendahnya bobot umbi (BU). Bobot umbi tertinggi diperoleh pada perlakuan FD suhu rendah $(2,238 \mathrm{~g})$ dan hasil terendah diperoleh pada kombinasi perlakuan FD +40 COU pada suhu tinggi $(0,021 \mathrm{~g})$.

Tabel 5. Pengaruh interaksi antara suhu dan tuber promoter terhadap diameter umbi terkecil (DUK), diameter umbi terbesar (DUB), dan rerata diameter umbi (RDU).

\begin{tabular}{cccc}
\hline Perlakuan & DUK $(\mathbf{m m})$ & DUB $(\mathbf{m m})$ & RDU (mm) \\
\hline Suhu Rendah & & & \\
\hline FD & $1,99 \mathrm{ab}$ & $12,34 \mathrm{~b}$ & $6,44 \mathrm{~b}$ \\
\hline FD $+\mathbf{1 0}$ COU & $1,47 \mathrm{ab}$ & $14,92 \mathrm{~b}$ & $7,58 \mathrm{~b}$ \\
\hline FD $+\mathbf{2 0}$ COU & $0,33 \mathrm{a}$ & $12,63 \mathrm{~b}$ & $6,24 \mathrm{~b}$ \\
\hline FD $+\mathbf{3 0}$ COU & $3,83 \mathrm{~b}$ & $13,65 \mathrm{~b}$ & $7,27 \mathrm{~b}$ \\
\hline FD +40 COU & $0,99 \mathrm{a}$ & $13,93 \mathrm{~b}$ & $5,82 \mathrm{ab}$ \\
\hline FD + 50 COU & $3,51 \mathrm{~b}$ & $13,95 \mathrm{~b}$ & $7,31 \mathrm{~b}$ \\
\hline IPB & $3,37 \mathrm{~b}$ & $13,82 \mathrm{~b}$ & $6,83 \mathrm{~b}$ \\
\hline Suhu Tinggi & & & \\
\hline FD & $1,11 \mathrm{a}$ & $1,41 \mathrm{a}$ & $1,21 \mathrm{a}$ \\
\hline FD $+\mathbf{1 0}$ COU & $1,21 \mathrm{a}$ & $1,32 \mathrm{a}$ & $1,21 \mathrm{a}$ \\
\hline FD $+\mathbf{2 0}$ COU & $1,12 \mathrm{a}$ & $1,41 \mathrm{a}$ & $1,32 \mathrm{a}$ \\
\hline
\end{tabular}




\begin{tabular}{cccc}
\hline FD +30 COU & $1,21 \mathrm{a}$ & $1,41 \mathrm{a}$ & $1,22 \mathrm{a}$ \\
\hline FD +40 COU & $1,11 \mathrm{a}$ & $1,32 \mathrm{a}$ & $1,21 \mathrm{a}$ \\
\hline FD $+\mathbf{5 0}$ COU & $1,12 \mathrm{a}$ & $1,42 \mathrm{a}$ & $1,31 \mathrm{a}$ \\
\hline IPB & $1,01 \mathrm{a}$ & $1,41 \mathrm{a}$ & $1,12 \mathrm{a}$ \\
\hline
\end{tabular}

Keterangan: angka-angka yang diikuti oleh huruf berbeda pada kolom yang sama berbeda nyata pada taraf $5 \%$. $\mathrm{FD}=$ formula dasar; FD $+10 \mathrm{CU}=$ Formula dasar ditambah 10 ppm Coumarin.

Ukuran umbi dinyatakan dengan diameter umbi paling kecil (DUK), diameter umbi paling besar (DUB), dan rerata diameter umbi (RDU). Secara umum, ukuran umbi yang besar diperoleh ketika tuber promoter dikombinasikan dengan suhu rendah. Kombinasi tuber promoter dengan suhu tinggi menghasilkan ukuran umbi yang kecilkecil (Tabel 5.).

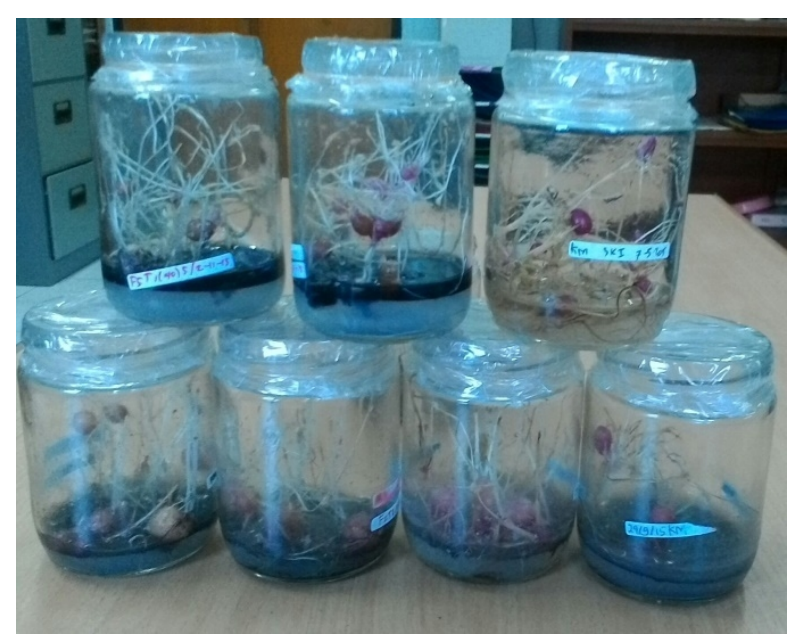

Gambar 1. Umbi mikro kentang merah yang dihasilkan oleh tuber promoter pada suhu $20+2^{\circ} \mathrm{C}$. Keterangan: a). Gambar bawah (dari kanan ke kiri): FD, FD+10 COU, FD+20 COU, dan FD+30 COU. Gambar atas (dari kiri ke kanan): FD + 40 COU, dan IPB

\section{PEMBAHASAN}

Tanaman kentang komersial (Solanum tuberosum L.) adalah tanaman yang menghendaki suhu $17-20{ }^{\circ} \mathrm{C}$ untuk tumbuh dan berproduksi secara maksimal (Stark and Love, 2003). Apabila kentang ditanam pada suhu tinggi, maka akan menghadapi masalah yang terkait dengan suhu tinggi, seperti naiknya biosintesis $\mathrm{GA}_{3}$ dan meningkatnya respirasi (Suharjo et al., 2008). Pada tanaman kentang, $\mathrm{GA}_{3}$ menghambat pembentukan umbi dan memacu tinggi tanaman. Fenomena seperti inilah yang ditemukan pada hasil penelitian ini, di mana pada suhu tinggi $(29 \pm$ $2{ }^{\circ} \mathrm{C}$ ) terjadi peningkatan tinggi tanaman dan penundaan keluarnya umbi. Selain itu, suhu tinggi juga berakibat pada menurunnya jumlah tanaman produktif, menurunnya jumlah umbi terbentuk, dan menurunnya bobot dan ukuran umbi (Tabel 1). Hasil serupa pernah dilaporkan oleh Agustina
(2006) yang menginduksi umbi mikro pada dua suhu berbeda $\left(18^{\circ} \mathrm{C}\right.$ dan $\left.25^{\circ} \mathrm{C}\right)$, di mana pada suhu $25^{\circ} \mathrm{C}$ jumlah umbi yang terbentuk lebih sedikit dan tinggi tanamannya lebih tinggi. Menurunnya jumlah umbi, persen tanaman produktif, ukuran umbi, dan bobot umbi juga pernah dilaporkan oleh Otroshy et al. (2009) ketika menaikkan suhu inkubasi dari $15^{\circ} \mathrm{C}$ menjadi $25^{\circ} \mathrm{C}$. Hasil penelitian ini mengkonfirmasi hasil penelitian sebelumnya bahwa suhu tinggi berpengaruh negatif terhadap inisiasi umbi kentang.

Upaya mengurangi pengaruh negatif suhu tinggi terhadap pembentukan umbi kentang dapat dilakukan dengan menurunkan suhu ruang inkubasi (pada penanaman secara in vitro) atau menurunkan suhu daerah perakaran (pada penanaman di dataran rendah). Selain itu, pengaruh suhu tinggi dapat ditekan dengan menghambat biosintesis $\mathrm{GA}_{3}$ atau menghambat aktivitas $\mathrm{GA}_{3}$ dengan 
aplikasi retardan. Pada penelitian ini efek negatif suhu tinggi diatasi dengan aplikasituber promoter, yang mengandung retardan untuk menekan kinerja $\mathrm{GA}_{3}$ dan mengandung bahan lain (auksin, sitokinin, arang aktif, chitosan, dan air kelapa) untuk memacu pembentukan umbi.

Hasilnya menunjukkan bahwa hampir semua tuber promoter yang diuji mempunyai kinerja lebih baik pada suhu rendah dibandingkan pada suhu tinggi. Pada suhu tinggi, tuber promoter kurang efektif dalam menginduksi umbi mikro kentang, yang ditunjukkan dengan WKU lebih lama, PTP lebih rendah, JU lebih sedikit, BU lebih sedikit, dan DU lebih kecil. Hal ini menunjukkan bahwa tuber promoter yang diuji tidak dapat mengatasi dampak negatif suhu tinggi. Hasil ini berbeda dengan laporan Suharjo et al. (2008), yang melaporkan bahwa beberapa jenis retardan (Paclobutrazol, CCC, Ancymidol, dan Coumarin) dapat mengatasi dampak negatif suhu tinggi $\left(30^{\circ} \mathrm{C}\right)$ sehingga pembentukan umbi mikro tidak terhambat dan dapat menghasilkan 6,7 umbi per botol. Pada penelitian ini umbi yang dihasilkan pada suhu tinggi tidak lebih dari 0.5 per botol.

Ada yang membedakan antara kondisi penelitian ini dan penelitian Suharjo et al. (2008), meskipun suhu inkubasi kedua penelitian itu relatif sama $\left(29 \pm 2^{\circ} \mathrm{C}\right.$ dan $30^{\circ} \mathrm{C}$ ). Suharjo et al. (2008) menggunakan media MS dengan retardan pada knsentrasi tinggi (4000 ppm Paclobutrazol, 1200 ppm CCC, 200 ppm Coumarin, dan 4 ppm Ancymidol). Pada penelitian ini, retardan yang diberikan adalah 10, 20, 30, 40, dan 50 ppm Coumarin. Meskipun tuber promoter itu juga mengandung auksin, sitokinin, chitosan, asam organik, dan air kelapa, namun demikian konsentrasinya masih sangat rendah sehingga hanya efektif untuk memacu pembentukan umbi pada suhu rendah. Artinya, diperlukan peningkatan konsentrasi unsur-unsur penyusun tuber promoter agar tuber promoter ini efektif dalam memacu pembentukan umbi mikro kentang pada suhu tinggi.

Pada penelitian ini semua formula tuber promoter yang diuji menunjukkan kinerja lebih baik dari tuber promoter formula IPB, baik pada suhu tinggi maupun suhu rendah (Tabel 3 dan 5). Temuan ini menjadi catatan yang menarik karena formula IPB, yang tersusun dari 2,4-D (10 ppm), Daminozide (100 ppm), dan air kelapa (10\%), sudah dipatenkan dan dilaporkan mampu menginduksi umbi mini sampai 17-33 buah hanya dari satu batang stek mikro (Matjik, 2003; Paten No: S0020000206/IDS 0000412) pada suhu rendah. Artinya, tuber promoter yang diuji pada penelitian ini mempunyai prospek yang sangat bagus untuk menggantikan formula IPB dalam menginduksi umbi mini di screenhouse pada suhu rendah. Visual umbi mikro yang terbentuk pada tiap formula tuber promoter dan formula IPB disajikan pada Gambar 1.

\section{KESIMPULAN}

Kesimpulan yang dapat ditarik dari penelitian ini adalah, bahwa:

1. Suhu tinggi menghambat pertumbuhan dan induksi umbi mikro.

2. Secara tunggal, semua formula tuber promoter lebih unggul dalam menginduksi umbi mikro dibandingkan formula IPB.

3. Formula tuber promoter yang diuji hanya efektif pada suhu rendah, meskipun kinerjanya jauh lebih baik dari formula IPB.

Hasil penelitian ini perlu ditindaklanjuti dengan menguji formula tuber promoter dalam menginduksi umbi mini di screenhouse.

\section{DAFTAR PUSTAKA}

Agustina. 2006. Penggunaan kinetin dan coumarin untuk memacu pembentukan umbi mikro kentang pada suhu yang berbeda. [Skripsi]. Fakultas Pertanian, Universitas Bengkulu.

Badoni A and Chauhan JS. 2010. Importance of potato micro tuber-seed material for farmers of Uttarakhand Hills. Int. J. Sustain. Agric. vol 2(1): 01-09.

Dhaka $M$ and Nailwal TK. 2015. High efficienty macropropagation of potato (Solanum tuberosum L.) cv. Kufru Jyoti 
in Kumaun Hills. J. Plant Breeding and Crop Sci. vol 7(7): 203-210. doi: 10.5897/JPBCS2015.0507

Fufa M and Diro M. 2014. Microtuber induction of two potato (Solanum tubersoum L.) varities. Adv. Crop Sci. Tech. vol 2(2): 122. doi: 10.4172/23298863.1000122

Kanwal A, Ali A, Shoaib K. 2006. In vitro microtuberization of potato (Solanum tuberosum L.) cultivar Kuroda- A new variety in Pakistan. Int. J. Agric and Biol. vol 8(3): 337-340.

Kawakami J and Iwama K. 2012. Effect of potato size on the growth and yield performance of field grown plants. Plant Prod. Sci. 15(2): 144-148.

Otroshy M, Nazarian F, Struik PC. 2009. Effects of temperature fluctuation during in vitro phase on in vitro microtuber production in different cultivars of potato (Solanum tuberosum L.). Plant Cell Tiss Organ Cult. vol 98(2): 213-218. doi: https://doi.org/10.1007/s11240-0099554-6

Piao XC, Chakrabarty D, Hahn EJ, Paek KY. 2002. A simple method for mass production of potato microtubers using a bioreactor system. Curr. Sci. vol 84 (25): 1129-1132.

Saha S, Ahmed M, Islam MM, Remme RN, Ali MR. 2013. Effect of different levels of sucrose on microtuberization and different substrates on minituber production resulted from potato meristem culture. J.Agric. Vet. Sci. vol 4(6): 58-62.

Stark KL. and Love SM. 2003. Potato Production System. California: Mcgraw Hill.

Suharjo UKJ. 2007. The use of polyetylene glycol (PEG) 8000 for rapid screening of potato genotypes for drought tolerance: Tuberization. J. Agrotropika. vol 12(1): 16-26.

Suharjo UKJ, Fahrurrozi, Sudjatmiko S. 2008. Memacu pembentukan umbi mikro kentang pada suhu tinggi dengan aplikasi paclobutrazol, coumarin, CCC, dan ancymidol. Prosiding Seminar Pekan Kentang Nasional. Lembang, Bandung, 22-23 Agustus 2008.

Suharjo UKJ, Herison C, Fahrurrozi. 2010. Keragaman tanaman kentang varitas Atlantik dan Granola di dataran medium (600 $\mathrm{m} \mathrm{dpl)} \mathrm{Bengkulu} \mathrm{pasca} \mathrm{iradiasi} \mathrm{sinar}$ gammat. Akta Agrosia. vol 13(1): 82-88.

Zakaria RA, Zanjani BM, Sedghi E. 2009. Effect of in vitro chitosan application on growth and minituber yield of Solanum tuberosum L. Plant Soil Env. vol 55 (6): 252-256.

Zhang $\mathrm{Y}$ and Donelly DJ. 1997. In vitro bioassay for salinity tolerance screening of potato. Potato Res. vol 40(3): 285-295. 